\title{
Attic Conversion - Hygrothermal Assessment of Historical Roof Truss
}

\author{
Katerina Sojkova ${ }^{1, *}$, and Kamil Stanek ${ }^{1}$ \\ ${ }^{1} \mathrm{CTU}$ in Prague, University Centre for Energy Efficient Buildings, Bustehrad, Czech Republic
}

\begin{abstract}
In the City of Prague centre, an investor had the intention to convert the unused attic space of a historical palace into office and exhibition floor. It was necessary to design such a solution that would not worsen the humidity conditions and would not jeopardize the original Renaissance roof truss. The requirements of the heritage protection agency and the architect predetermined the use of very efficient thermal insulation above the rafters. The paper introduces and assesses several design solutions for: (1) new roofing layers and (2) the critical detail near the eaves, including variants with active heating elements. The assessment was based on results of 2D steady-state hygrothermal modelling using two criteria: (1) the interior surface temperature under winter design boundary conditions and (2) the relative humidity in the area of the timber elements under average January boundary conditions. The results showed hygrothermal implications of different design measures and helped to identify acceptable solutions for further project phases.
\end{abstract}

\section{Introduction}

In the City of Prague centre, an investor had the intention to convert an unused attic space of a historical palace under heritage protection into an office and exhibition floor. The palace had an original Renaissance roof truss, see Fig. 1, with most of the elements in good condition except the area at the eaves where progressive decay of sprockets, wall plates, rafter ends, and tie-beam heads was recorded. The roofing was made of ceramic tiles (traditional mission style), stacked on battens and counterbattens, without protective waterproofing.

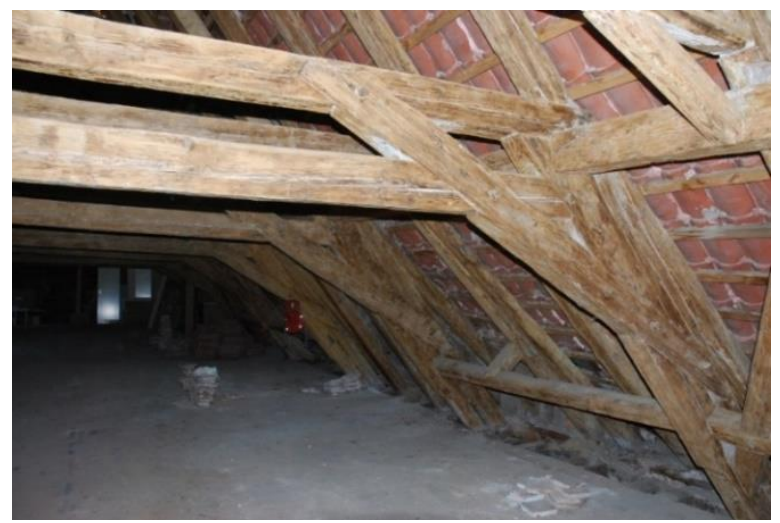

Fig. 1. Original Renaissance roof truss (spruce wood).

The requirements of the heritage protection agency were (1) to preserve the outer appearance of the roof, and (2) to assess whether the attic refurbishment will not worsen the hygrothermal conditions of timber truss elements and thus endanger their service life. The requirement of the architect was to leave most of the timber elements of the roof visible from the interior.
The paper presents design and hygrothermal assessment of several refurbishment options that would ensure new, energy-acceptable, economical, and moisture safe use of the attic space. A special attention was paid to the area at the eaves where several moisture sensitive timber elements are in direct contact with masonry.

\section{Methods}

\subsection{Proposed solutions and assessed variants}

The design and assessment was carried out in two main steps. Firstly, a new roofing was proposed and assessed to meet the requirements of the heritage protection agency and the architect. Secondly, a solution was proposed for the sensitive detail at the eaves, see Fig. 2, where the roofing meets the masonry wall.

Both the roofing and the detail at the eaves were worked out in several variants, bearing in mind the practical feasibility of the proposed measures.

\subsubsection{New roofing}

Emphasis in the design of new roofing was put on the balance between its thermal transmittance and overall thickness. A special attention was paid to the integrity of the vapour- and thermal insulation layers. Both of these key layers are therefore located above the rafters to minimize the number of penetrations. The use of an overrafter system also generally ensures that the key timber elements of the historic truss are completely in the interior, i.e. in temperature- and humidity stable environment. The requirement of the heritage protection agency to minimize

Corresponding author: katerina.sojkova@cvut.cz 
the change in roof geometry predetermined the use of a very effective thermal insulation. Two variants were considered:

- Aerogel (S1), $U$-value $=0.271 \mathrm{~W} /\left(\mathrm{m}^{2} \mathrm{~K}\right)$,

- Vacuum panels laminated in expanded polystyrene (S2), $U$-value $=0.245 \mathrm{~W} /\left(\mathrm{m}^{2} \mathrm{~K}\right)$.

The variants of new roofing are shown in Fig. 3, hygrothermal characteristics of the individual materials are given in Tab. 1.

In both variants, the total thickness of thermal insulation was $50 \mathrm{~mm}$. A bituminous membrane was proposed as a vapour barrier due to its high mechanical resistance and the possibility of bonding the thermal insulation with asphalt adhesive (especially vacuum panels).

For structural reasons, and to maintain high thermal resistance at all points of the roofing, strips made of rigid polystyrene foam (Compacfoam, thermal conductivity $\lambda=0.04 \mathrm{~W} /(\mathrm{mK}))$ were placed under counter-battens. In the variant $\mathrm{S} 2$, the vacuum panels of limited size were completed with PIR insulation.

In both variants, the roofing was completed with vapour permeable underlay foil, ventilated air gap, and original ceramic tiles (or replicas).

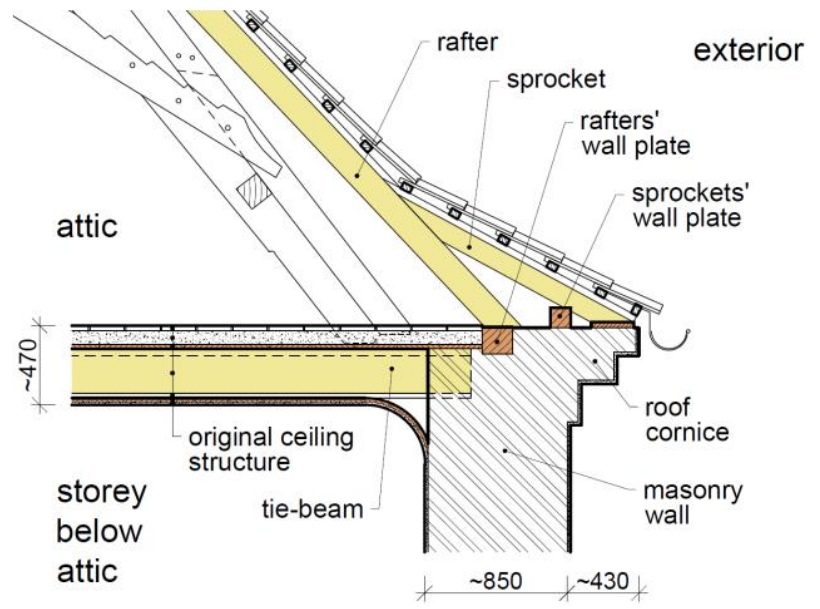

Fig. 2. Detail at the eaves (vertical section). [1]

S1: AEROGEL

S2: VACUUM INSULATION

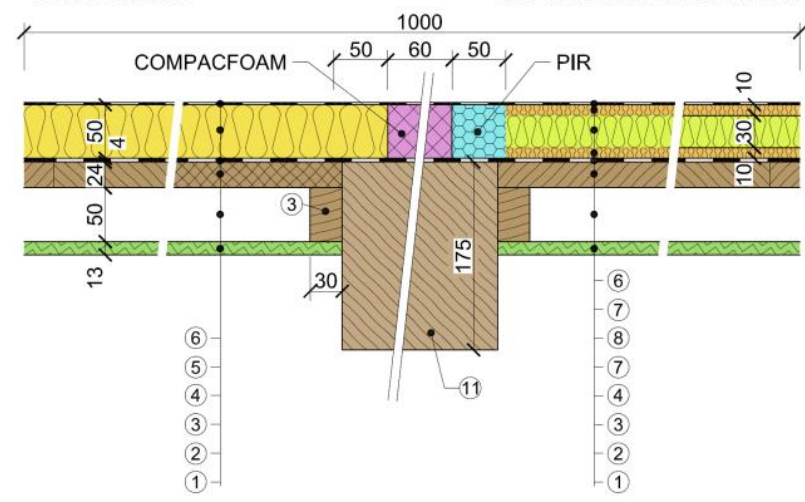

Fig. 3. Variants of roofing:

Left - variant S1 with aerogel, $U=0.271 \mathrm{~W} /\left(\mathrm{m}^{2} \mathrm{~K}\right)$;

Right - variant S2 with vacuum panels, $U=0.245 \mathrm{~W} /\left(\mathrm{m}^{2} \mathrm{~K}\right)$.

For hygrothermal parameters of the materials see Tab. 1.
Table 1. Hygrothermal parameters of the materials depicted in Fig. 3.

\begin{tabular}{|c|l|c|c|}
\hline No. & Material & $\begin{array}{c}\lambda \\
{[\mathbf{W} /(\mathbf{m K})]}\end{array}$ & $\begin{array}{c}\boldsymbol{\mu} \\
{[-]}\end{array}$ \\
\hline 1 & Gypsum board & 0.210 & 10 \\
\hline 2 & Air layer, unventilated & 0.294 & 0.2 \\
\hline 3 & Softwood, decking with gaps & 0.180 & 10 \\
\hline 4 & Bituminous membrane & 0.210 & 30000 \\
\hline 5 & Aerogel & 0.015 & 5 \\
\hline 6 & Underlay foil, vapour permeable & 0.350 & 130 \\
\hline 7 & Expanded polystyrene & 0.037 & 50 \\
\hline 8 & Vacuum panels & 0.008 & 10000000 \\
\hline 9 & Compacfoam & 0.040 & 25 \\
\hline 10 & PIR & 0.028 & 20 \\
\hline 11 & Softwood, solid & 0.180 & 100 \\
\hline
\end{tabular}

\subsubsection{Detail at the eaves}

The detail at the eaves was assessed in three basic variants: V1 (current state), V2 and V3 (new solutions), which in some cases were further branched into sub-variants. These differed in the position of the vapour barrier and the primary insulation layer (V2, V3), the use of additional thermal insulation in the sprockets' area (V3-i), the position of the gypsum boards (V3-b), or the use of a heating cable to further increase the temperature in the critical areas (V2-t, V3-t). In all variants, the roof cornice was insulated with aerogel $(20 \mathrm{~mm}$ thick). The basic characteristics of the variants are depicted in Fig. 4.

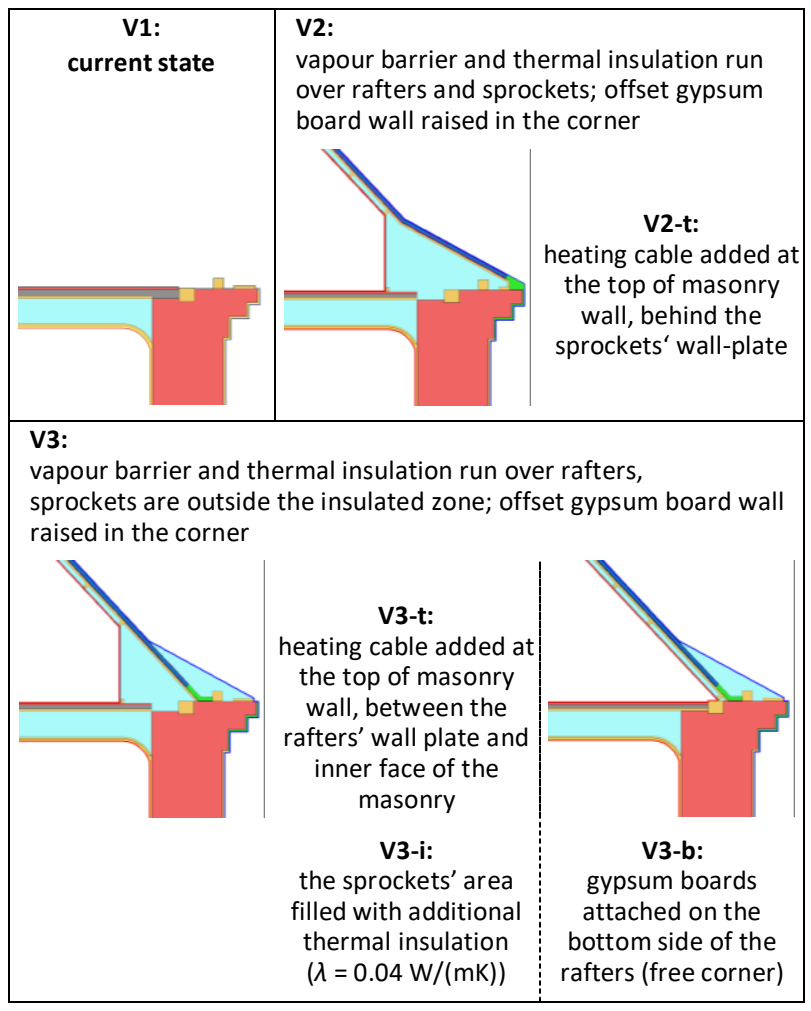

Fig. 4. Variants of the detail at the eaves.

\subsection{Computational model}

The hygrothermal assessment was performed using the FEM software Area [2] which computes two-dimensional steady-state heat and water vapour transport in building 
structures according to EN ISO 10211 [3], ČSN 730540 [4-6] and EN ISO 13788 [7].

The detail at the eaves was assessed in vertical section, therefore the timber elements of the roof truss parallel to the section plane, such as tie-beams, rafters, and sprockets, were not included in the computational model.

The assessment was carried out for two sets of exterior boundary conditions: (1) average January conditions and (2) winter design conditions. Standard values were used for interior boundary conditions. The boundary conditions are summarized in Tab. 2.

Table 2. Boundary conditions. $[5,8]$

\begin{tabular}{|c|c|c|c|c|}
\hline Space & $\begin{array}{c}\text { Air } \\
\text { temp. } \\
\theta_{\mathrm{a}}\left[{ }^{\circ} \mathrm{C}\right]\end{array}$ & $\begin{array}{c}\text { Surface heat } \\
\text { resistance } \\
R_{\mathrm{s}}\left[\mathbf{m}^{2} \mathbf{K} / \mathbf{W}\right]\end{array}$ & $\begin{array}{c}\text { Relative } \\
\text { humidity } \\
\varphi[\%]\end{array}$ & $\begin{array}{c}\text { Mass } \\
\text { transfer } \\
\text { coefficient } \\
\alpha_{\mathrm{d}}[\mathbf{s} / \mathbf{m}] \\
\end{array}$ \\
\hline \multicolumn{5}{|c|}{ January conditions - monthly average } \\
\hline $\begin{array}{l}\text { Storey bellow } \\
\text { the attic }\end{array}$ & 22.0 & \multirow{3}{*}{0.25} & 46.0 & \multirow{3}{*}{10} \\
\hline $\begin{array}{l}\text { Attic } \\
\text { - refurbished }\end{array}$ & 20.6 & & 50.1 & \\
\hline $\begin{array}{l}\text { Attic } \\
\text { - current state }\end{array}$ & -2.4 & & 81.2 & \\
\hline Exterior & -2.4 & \begin{tabular}{|l|l|}
0.04 &
\end{tabular} & 81.2 & 20 \\
\hline \multicolumn{5}{|c|}{ Winter design conditions } \\
\hline $\begin{array}{l}\text { Storey bellow } \\
\text { the attic }\end{array}$ & 22.0 & \multirow{3}{*}{0.25} & 55.0 & \multirow{3}{*}{10} \\
\hline $\begin{array}{l}\text { Attic } \\
- \text { refurbished }\end{array}$ & 20.6 & & 50.0 & \\
\hline $\begin{array}{l}\text { Attic } \\
\text { - current state }\end{array}$ & -13.0 & & 84.0 & \\
\hline Exterior & -13.0 & 0.04 & 84.0 & 20 \\
\hline
\end{tabular}

\subsection{Evaluation method and requirements}

Hygrothermal performance of the new roofing as well as the detail at the eaves was evaluated based on two criteria according to ČSN 730540 [4]:

- minimum interior surface temperature at winter design conditions,

- moisture safety of key timber elements of the roof truss at average January conditions.

\subsubsection{Minimum interior surface temperature}

According to the standard ČSN 730540-2 [4] the interior surface temperature of building structures and their connections has to be high enough so that the relative humidity at the surface does not exceed $80 \%$ (risk of mould growth). The minimum acceptable values of interior surface temperature in this case are:

- $12.2^{\circ} \mathrm{C}$ for the attic,

- $15.1{ }^{\circ} \mathrm{C}$ for the storey bellow the attic.

The different values result from different interior boundary conditions, see Tab. 3 .

\subsubsection{Moisture safety of key timber elements}

The moisture safety of built-in timber elements was evaluated on the basis of relative humidity at the place of their installation under average January conditions. The limit value, which may already pose moisture and microbiological risks, is assumed to be $85 \%$. This value is derived from ČSN 730540-2 [4], according to which the equilibrium moisture content of wood or wood-based materials shall not exceed $18 \%$ under standard conditions of use.

The relative humidity at which the wood reaches a certain equilibrium moisture content, EMC, can be read from the sorption curve (the dependence of EMC of the material on the relative air humidity). For the spruce wood, the EMC of $18 \%$ corresponds to a relative air humidity of $85 \%$ (see Figure 5). Accordingly, areas with relative humidity higher than $85 \%$ are highlighted in graphic outputs (section 3). This makes it easier to see if any of the timber elements exceeds the moisture limit.

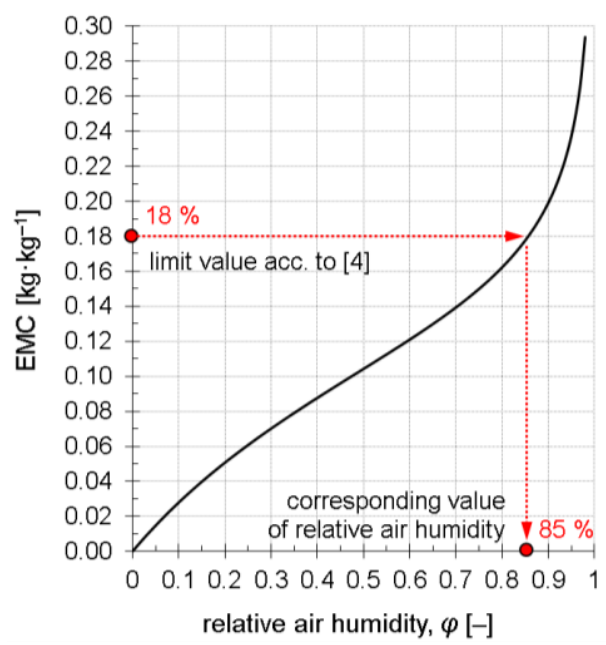

Fig. 5. Sorption curve of solid spruce wood and derivation of the limit value of $85 \%$ of relative air humidity. [9]

\section{Results}

\subsection{New roofing}

Both variants of new roofing (S1 with aerogel and S2 with vacuum panels) meet the requirement for the minimum interior surface temperature. Also humidity in the areas of timber elements stays within the safe limits $(<85 \%)$. The humidity is slightly lower in the variant $\mathrm{S} 1$, with the value of $71.2 \%$ on the upper surface of the rafters. The calculations also show that the relative humidity on the upper surface of the rafters is lower than the relative humidity of the external air, i.e. lower than in the current state. The new over-rafter roofing thus does not increase moisture risk of the roof truss. The results are summarized in Fig. 6 and Tab. 3.

Table 3. Summary of results for the roofing

\begin{tabular}{|l|c|c|}
\hline Var. & $\begin{array}{c}\text { Minimum interior } \\
\text { surface temperature } \\
\text { in winter design } \\
\text { cond. } \boldsymbol{\theta}_{\text {si }} \text { (attic) }\left[{ }^{\circ} \mathbf{C}\right]\end{array}$ & $\begin{array}{c}\text { Moisture safety } \\
\text { of key timber elements } \\
\text { in average January } \\
\text { conditions }\end{array}$ \\
\hline S1 (aerogel) & 18.0 & safe \\
\hline S2 (vacuum) & 17.9 & safe \\
\hline
\end{tabular}

Legend: green cells - the requirements are met (see section 2.3) 

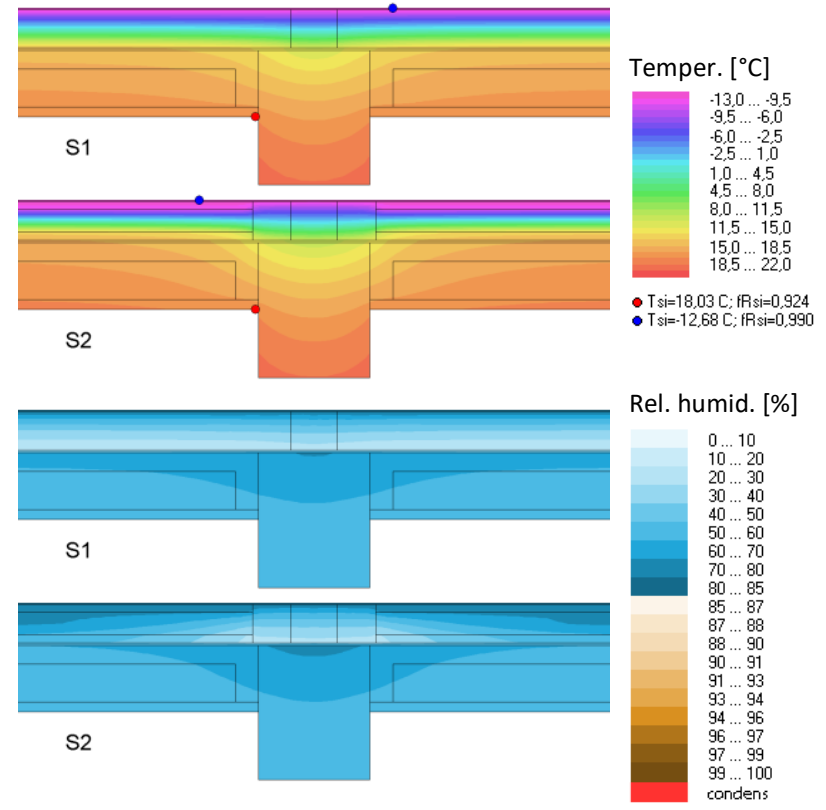

Fig. 6. Roofing S1 (aerogel) and S2 (vacuum panels):

Top - temperature at winter design conditions;

Bottom- relative humidity at average January conditions.

The results show no fundamental difference in hygrothermal performance of both S1 and S2 variants. The variant $\mathrm{S} 2$ with vacuum insulation panels was chosen for further assessment with regard to slightly lower thermal transmittance $\left(U\right.$-value $\left.=0.245 \mathrm{~W} /\left(\mathrm{m}^{2} \mathrm{~K}\right)\right)$ and lower price (at the time of the study the price of vacuum panels was $165 \mathrm{EUR} / \mathrm{m}^{2}$ ).

\subsection{Detail at the eaves}

Results of all considered variants are summarized in Tab. 4. Detailed evaluation and graphical results for the individual variants are presented in the following sections.

Table 4. Summary of results for the critical detail at the eaves.

\begin{tabular}{|c|c|c|c|}
\hline \multirow[t]{2}{*}{ Var. } & \multicolumn{2}{|c|}{$\begin{array}{c}\text { Minimum interior surface } \\
\text { temper. in winter design } \\
\text { cond. } \theta_{\mathrm{si}}\left[{ }^{\circ} \mathrm{C}\right]\end{array}$} & \multirow{2}{*}{$\begin{array}{c}\text { Moisture safety } \\
\text { of key timber } \\
\text { elements in average } \\
\text { January conditions }\end{array}$} \\
\hline & $\begin{array}{c}\text { Storey } \\
\text { bellow attic }\end{array}$ & Attic & \\
\hline V1 & 12.4 & - & risk \\
\hline V2 & 15.6 & 16.0 & condensation \\
\hline$V 2-t$ & 15.9 & 17.9 & safe \\
\hline V3 & 15.5 & 16.6 & risk \\
\hline$V 3-t$ & 15.9 & 18.9 & safe \\
\hline V3-i & 15.6 & 17.2 & safe \\
\hline V3-b & 15.5 & 12.2 & risk \\
\hline
\end{tabular}

Legend:

green cells - the requirements are met (see section 2.3)

risk - relative humidity in the area of timber elements exceeds $85 \%$, but no condensation is predicted

red cells - the minimum interior surface temperature is lower than the required value / condensation is predicted in the area of timber elements

\subsubsection{Variant V1 (current state)}

Computational assessment of the current state shows that the interior surface temperature in the wall-ceiling corner drops to $12.4{ }^{\circ} \mathrm{C}$ under winter design conditions (see the blue point in Fig. 7, top), and does not meet the requirement.

In terms of water vapour diffusion, the assessment under average January conditions did not identify a significant risk for timber elements. The humidity limit of $85 \%$ is exceeded only in a small area within the ceiling structure near to masonry wall. The humidity here reaches $90 \%$ which may threaten wooden decking and tie-beams ends. In other timber elements the humidity stays below the limit. The results are shown in Fig. 7.

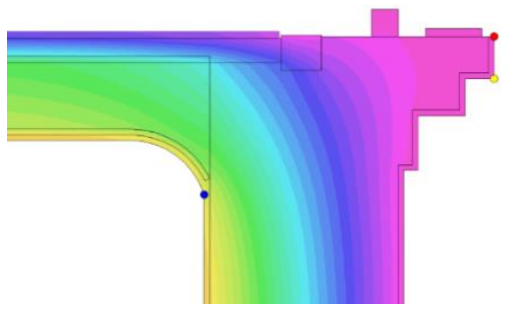

Temperature $\left[{ }^{\circ} \mathrm{C}\right]$
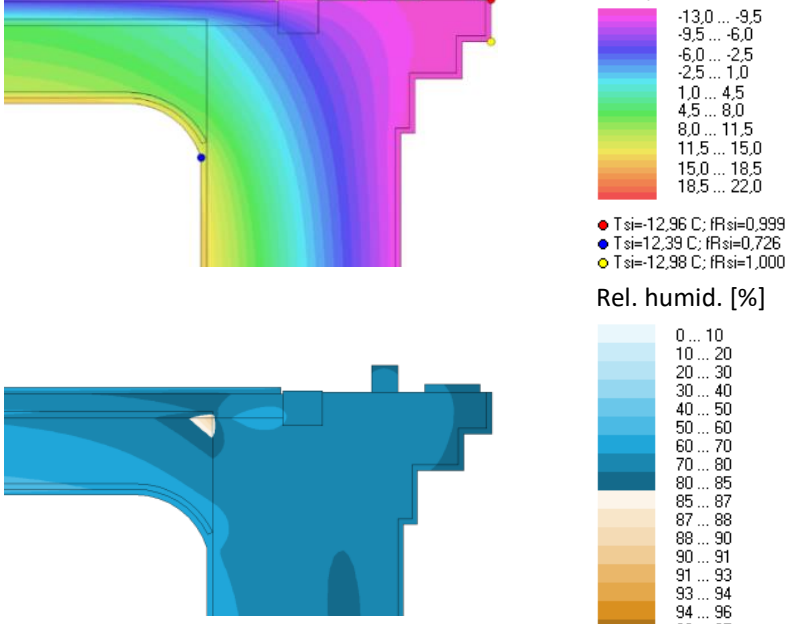

Rel. humid. [\%]

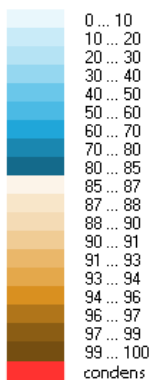

Fig. 7. Variant V1 (current state):

Top - temperature in winter design conditions ;

Bottom - relative humidity in average January conditions.

\subsubsection{Variants V2}

In the variants $\mathrm{V} 2$, the insulating layer is placed over the rafters and sprockets, and the offset gypsum board wall is raised in the attic corner.

The interior surface temperature of the wall-ceiling corner in the storey bellow the attic is higher by $3.3{ }^{\circ} \mathrm{C}$ compared to the current state and meets the requirement. The temperature of the interior surfaces in the attic is also sufficiently high, for both the V2 variants.

The basic variant without the heating cable (V2) shows increased relative humidity at the sprockets' wall plate and even condensation in the area behind. The heating cable placed to this critical area ensures elimination of the moisture risk (V2-t). The heating power required under average January conditions is $13 \mathrm{~W} / \mathrm{m}$ and the temperature at the cable is $19{ }^{\circ} \mathrm{C}$. An additional calculations showed that it would be $25 \mathrm{~W} / \mathrm{m}^{2}$ and $24{ }^{\circ} \mathrm{C}$ under winter design conditions, which is easily acceptable. The positive effect of the heating cable on temperature and humidity in the critical area is evident in Fig. 8. 


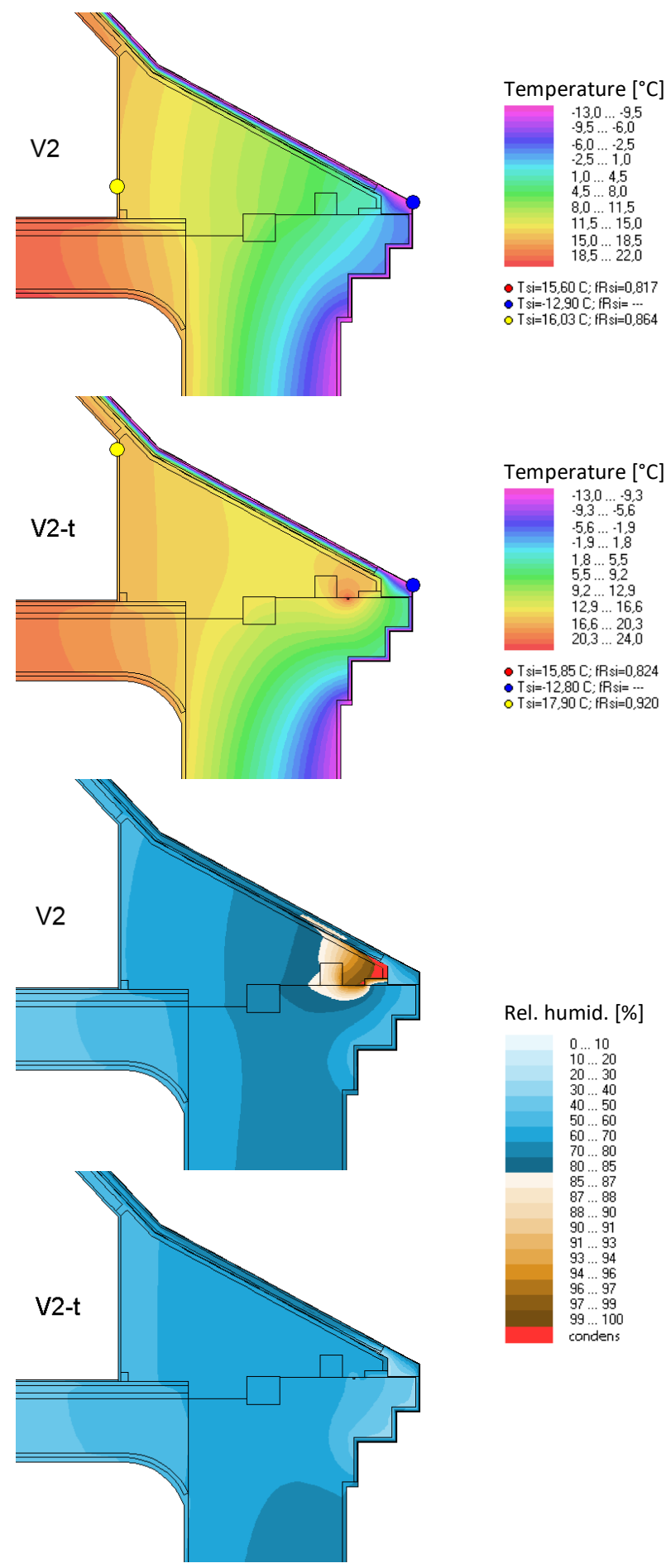

Fig. 8. Variants V2:

Top - temperature in winter design conditions (note: temperature scale differs for the variant with heating cable);

Bottom - relative humidity in average January conditions.

\subsubsection{Variants V3}

In the variants V3, the insulating layer is placed over the rafters, while the sprockets are left outside the insulated zone. The offset gypsum board wall is raised in the attic corner, except the sub-variant V3-b where the gypsum boards go along the rafters to the floor.

The temperature of interior surfaces is sufficiently high for all the V3 variants except the sub-variant V3-b, where the requirement is not met in the sharp inner corner near the attic floor (see the blue point at given variant in Fig. 9, top). This is because the air volume behind the offset gypsum board wall acts as an additional thermal resistance and thus contributes to higher surface temperature. On the other hand, from the perspective of temperature- and consequently humidity distribution in the area of timber elements, the gypsum board wall has the opposite effect.

The basic variant V3, and also the sub-variant V3-b, show increased relative humidity at the interface between the new roofing layers and the masonry wall, however, condensation does not occur here. The heating cable placed between the rafters' wall plate and the inner face of the masonry wall (V3-t) is able to eliminate the moisture risk. The cable position was chosen to allow an easy service access to the cable, however, at the cost of less ideal heat distribution with respect to the area of the highest humidity. It resulted in slightly higher heating power as well as the temperature at the cable at average January conditions: $15 \mathrm{~W} / \mathrm{m}$ and $24{ }^{\circ} \mathrm{C}$. An additional calculations showed that it would be $40 \mathrm{~W} / \mathrm{m}^{2}$ and $37^{\circ} \mathrm{C}$ under winter design conditions, which is still acceptable.

Filling the sprockets' area with additional thermal insulation (V3-i) further increases the interior surface temperature in the attic. At the same time, this measure positively affects the humidity in the area of timber elements, as shown in Fig. 9. In this sub-variant, the requirement on moisture safety is met by passive measures only, i.e. without the heating cable.

\section{Discussion}

The computational assessment of the current state did not identify any significant risk for the timber elements within the assessed detail at the eaves in terms of water vapour diffusion. The current poor condition of the sprockets, wall plates, rafter ends, and tie-beam heads embedded in masonry wall, is probably due to causes other than condensation of water vapour diffusing from the interior (e.g. rain water leakage).

The proposed refurbishment strategy using an overrafter insulating roofing ensures that most of the timber elements of the historic truss are completely in the interior, i.e. in a temperature- and humidity stable environment. In the design of a new solution at the eaves, emphasis was put on the integrity of vapour- and thermal insulation layers, especially in the connection of the new roofing to the masonry wall. A total of 6 variants of this detail was further designed and assessed, besides the current state.

In principle, the variants with a heating cable at the top of the masonry gave better results (higher surface temperature, lower humidity in the area of timber elements), of which the recommended variant is V2-t. It is a solution with vapour- and thermal insulation layers over the sprockets, an offset gypsum board wall, and a heating cable at the top of the masonry wall behind the sprockets' wall plate, i.e. in the area of the highest relative humidity. The required power of the heating cable is low and the temperature here stays within safe limits $(13 \mathrm{~W} / \mathrm{m}$ and $19{ }^{\circ} \mathrm{C}$ under average January conditions). The 


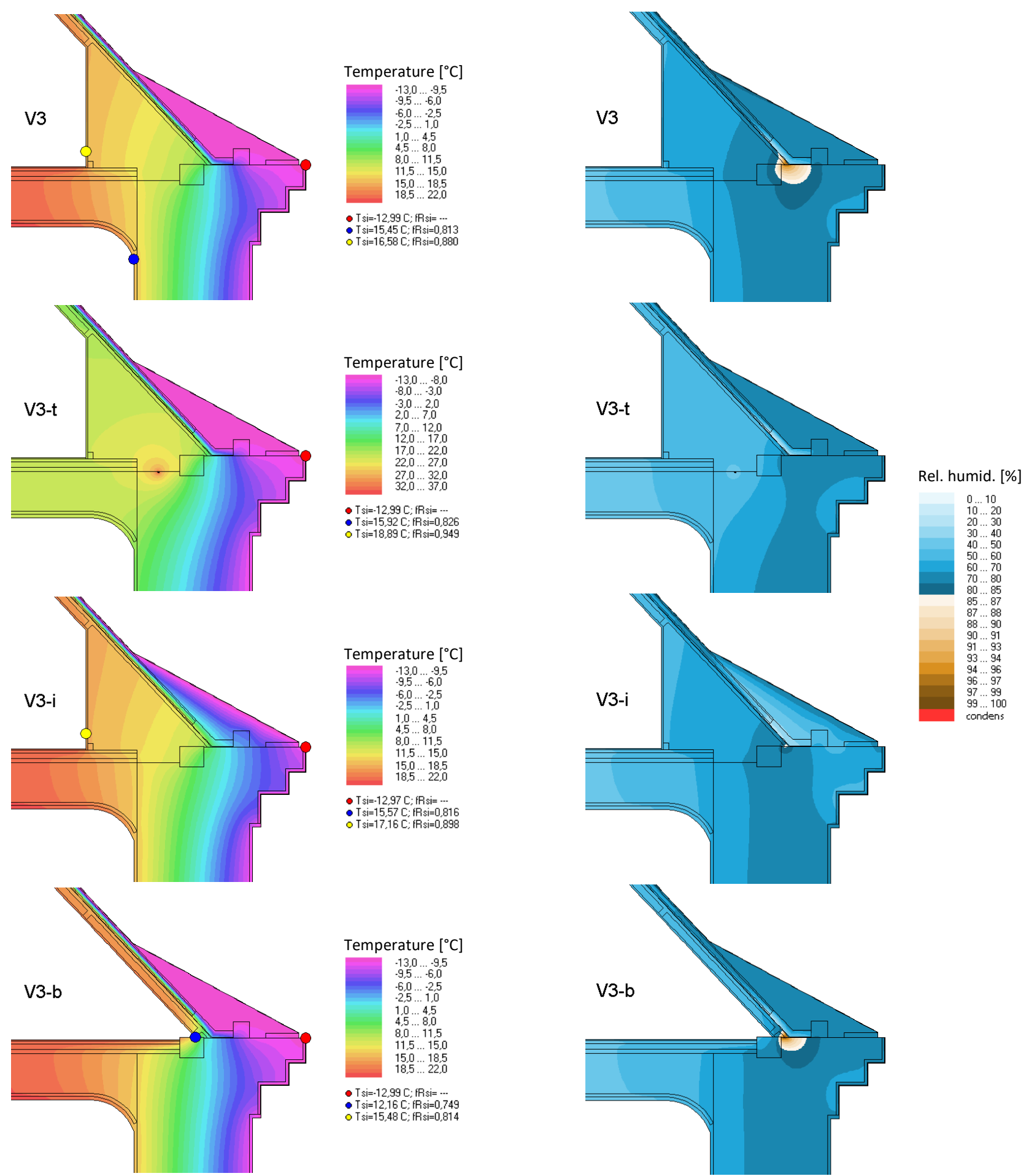

Fig. 9. Variants V3:

Left - temperature at winter design conditions (note: temperature scale differs for the variant with heating cable);

Right - relative humidity at average January conditions.

advantage of this solution, or more precisely of all variants with the offset gypsum board wall, is creating of an installation space for electrical, heating or airconditioning distribution elements. The heating cable may be further provided with an automatic power control based on a signal from humidity and/or temperature sensors located in critical areas, ensuring suitable microclimate throughout the year. However, it should be emphasized that a long-term moisture safety of this recommended solution largely depends on the use of the heating cable. The same solution, but without the heating cable (variant V2), is still satisfactory from the point of view of interior surface temperature, but it already shows increased humidity at the sprockets' wall-plate and even condensation in the corner where the sprockets meet the top of the masonry wall.

Of the variants without the heating cable, the best hygrothermal performance exhibits the variant V3-i. It is a solution with the vapour- and thermal insulation layers placed over the rafters, an offset gypsum board wall, and 
the sprockets' area filled with additional thermal insulation. Even in this case the use a heating cable may be recommended as a reserve for less favourable boundary conditions. Its suitable position would be again on the top of the masonry wall between the wall plates.

An important part of both recommended variants is the insulation of the roof cornice bellow the eaves with $20 \mathrm{~mm}$ thick aerogel boards. Omitting this measure (e.g. due to heritage protection requirements) would lead to lower temperature and increased humidity at the top of the masonry.

Moisture safety of timber elements in sensitive areas could be further increased by using an air conditioning with lower setpoint of relative humidity during cold periods, e.g. $40 \% \leq \varphi_{\mathrm{i}} \leq 45 \%$. It applies for the attic as well as for the storey below.

Based on the hygrothermal assessment, it can be stated that the attic can be refurbished without compromising the timber elements of the historical roof truss. However, the chosen calculation method involves some simplifications. One of them is a steady state calculation method, which however moves the results rather to the safe side, especially for the core of timber elements.

Besides, wood decay organisms need certain time to growth. For example, time needed for germination of mould spores on wood at the worst acceptable conditions within the assessed details $\left(85 \% \mathrm{RH}\right.$ and $\left.10^{\circ} \mathrm{C}\right)$ exceeds three months [11]. Wood decay fungi need even higher steady humidity for germination.

The critical details should be assessed at a later stage by more detailed calculation methods that take into account the influence of timber elements parallel to the section plane (namely tie-beams, rafters, sprockets).

This work has been supported by the Ministry of Education, Youth and Sports within National Sustainability Programme I (NPU I), project No. LO1605 - University Centre for Energy Efficient Buildings - Sustainability Phase.

\section{Reference}

1. Project documentation. Vít Mlázovský, 6/2018.

2. Area 2017. Svoboda software. http://kcad.cz/cz/stavebni-fyzika/tepelna-technika

3. ČSN EN ISO 10211. Thermal bridges in building construction - Heat flows and surface temperatures Detailed calculations. (2009)

4. ČSN 730540-2 (+Z1). Thermal protection of buildings - Part 2: Requirements. (2011)

5. ČSN 730540-3. Thermal protection of buildings Part 3: Design value quantities. (2005)

6. ČSN 730540-4. Thermal protection of buildings Part 4: Calculation methods. (2005)

7. ČSN EN ISO 13788. Hygrothermal performance of building components and building elements - Internal surface temperature to avoid critical surface humidity and interstitial condensation - Calculation methods. (2013)
8. NKP ČR $30-V$. Květoň: Air temperature norms in the Czech Republic in the period 1961-1990 and selected temperature characteristics of the period 1961-2000, C̆HMÚ (2001)

9. J. Richter, Laboratory measurements performed in 2018 at UCEEB, CTU in Prague (unpublished).

10. K. Sojková, K. Staněk, Hygrothermal assessment of the historical roof truss in Malá Strana, final report. UCEEB, CTU in Prague (2018)

11. A . Hukka, H.A. Viitanen, A mathematical model for mould growth on wooden material. Wood Sci. Technol. 33(6): 475-485 (1999) 